\title{
Evaluation of Psychopathology and Quality of Life in Children with Celiac Disease and their Parents
}

\author{
Çölyaklı Çocuklarda ve Ebeveynlerinde Psikopatoloji ve Yaşam Kalitesinin Değerlendirilmesi
}

Aziz Kara, Esra Demirci, Sevgi Ozmen

Erciyes University Hospital Child and Adolescent Psychiatry Department, Kayseri, Turkey

\section{ABSTRACT}

Objective: Celiac disease is a chronic disorder which is among common causes of malabsorption at childhood and can affect children and adults lifelong. Celiac disease negatively affects psychosocial development of children and adolescents and impairs health-related quality of life. In this study, it was aimed to assess levels of depression and anxiety in children and adolescents with Celiac disease, relationship between these parameters and quality of life in the patients and their mothers.

Method : Forty children and adolescents with Celiac disease (aged 8-18 years) who were followed in Pediatric Gastroenterology Department of Erciyes University, Medicine School for at least 6 months and their mothers were included to the study. Forty age- and sex-matched subjects and their mothers were employed as control group. In all children and adolescents, it was asked to complete 'Depression Scale for Children, State-Trait Anxiety Inventory and Pediatric Quality of Life Inventory'. All mothers were asked to complete 'Posttraumatic Stress Disorder Scale and Quality of Life Inventory'.

Results : Each group consisted of 17 males (42.5\%) and 23 females (57.5\%). In each groups, there are $22(55 \%)$ individuals in the $8-12$ age group and $18(45 \%)$ individuals in the 13-18 age group. No significant difference was detected in depression scale scores between children and adolescents with Celiac disease and controls. Anxiety levels were found to be higher in pediatric age group when compared to controls while no significant difference was detected between adolescents and controls. No significant difference was detected in perception of quality of life in children and adolescents and their mothers in both groups. Post-traumatic stress level was found to be higher in mothers of children and adolescents with Celiac disease when compared to those in mothers of controls.

Conclusion : There was an increase in anxiety levels in children with celiac diagnoses and an increase in trauma symptoms in their mothers and no difference in quality of life was found. It was concluded that Celiac disease affecting children and their family with many problems and impaired quality of life in children and adolescents, but many factors play role in this process.

Key Words: Celiac, Children, Adolescents, Psychopathology, Quality of Life

Received: 05.17 .2018

Accepted:06.08.2018

\section{ÖZET}

Giriş: Çölyak hastalığı çocukluk çağının yaygın malabsorpsiyon nedenleri arasında bulunan, çocuk ve yetişkinleri yaşam boyu etkileyebilen kronik bir hastalıktır. Çölyak çocuk ve ergenlerin psikososyal gelişimlerini olumsuz etkilemekte ve sağlıkla ilgili yaşam kalitelerini düşürebilmektedir. Bu çalışmada çölyaklı çocuk ve ergenlerde depresyon ve anksiyete düzeyleri ile, hasta ve annelerinin yaşam kalitelerinin, ayrıca bu parametreler arasındaki ilişkinin değerlendirilmesi amaçlanmıştır.

Yöntem : Çalışmaya Erciyes Üniversitesi Tıp Fakültesi Çocuk Gastroenterolojisi Bilim Dalı'nda çölyak tanısı ile takip edilmekte olan 8-18 yaş aralığında 40 çocuk, ergen ve anneleri dahil edildi. Kontrol grubu hasta grubu ile yaş ve cinsiyet açısından eşleştirilmiş 40 çocuk, ergen ve annelerinden oluşturuldu. Çalışmaya katılan tüm çocuk ve ergenlerden 'Çocuklar İçin Depresyon Ölçeği (ÇDÖ), Çocuklar için Durumluk-Sürekli Kaygı Envanteri (ÇDSKE), Çocuklar İçin Yaşam Kalitesi Ölçeği (ÇiYKÖ)'ni doldurmaları istendi. Annelerden ise 'Post Travmatik Stres Bozukluğu Soru Listesi-Sivil Versiyonu (PTSB-SV) ve Kısa form 36 (SF-36)'yı doldurması istendi.

Bulgular: Çölyak ve kontrol grubunun 17 tanesi erkek (\%42,5), 23 tanesi kız $(\% 57,5)$ olgu olup, 8-12 yaş grubunda 22 (\%55), 13-18 yaş grubunda da 18 (\%45) çocuk bulunmaktadır. Çölyak grubu ile kontrol grubu arasında depresyon ölçeği puanları arasında fark saptanmadı. Anksiyete düzeyleri çocuk yaş grubu çölyak hastalarında kontrollere göre yüksek bulunmuşken ergen yaş grubunda fark tespit edilmedi. Çocuk ve ergenlerin yaşam kalitesi algısı ve annelerin kendileriyle ilgili yaşam kalitesi algıları arasında fark saptanmadı. Annelerin travma sonrası stres bozukluğu belirti düzeyleri hem çocuk hem de ergen grubunda çölyaklı bireylerin annelerinde kontrollere göre daha yüksek saptandı.

Sonuç: Çölyak tanılı çocuklarda anksiyete düzeylerinde yükseklik ve annelerinde travma belirtilerinde artış bulunmuş olup yaşam kalitesi açısından fark tespit edilmemiştir.Çölyak tanısının çocuk ve ailesini birçok yönden olumsuz etkilediği fakat, psikiyatrik hastalıkların ortaya çıkması ve yaşam kalitesinin düşmesinde tek başına yeterli olmadığı, bu süreçte çok daha fazla değişkenin rol oynadığı düşünülmüştür.

Anahtar Sözcükler: Çölyak, Çocuk, Ergen, Psikopatoloji, Yaşam Kalitesi

Geliş Tarihi: 17.05 .2018

Kabul Tarihi:08.06.2018 


\section{INTRODUCTION}

Celiac disease (CD), which is among the common causes of malabsorption in childhood, is a lifelong disorder affecting both children and adults (1). The prevalence of CD has risen in recent years and is currently about $1 \%$ in Turkish population as similar throughout the world (2). Immunological mechanisms, triggered by gluten ingestion in genetically susceptible individuals, play the major role in the development of CD (3).It is thought that immunological reactions result in physical and psychiatric symptoms. Increased inflammation contributes to the development of psychiatric symptoms such as cognitive and emotional symptoms, confusion, psychomotor slowingand decreased motivation (4-8).Furthermore, there may be mental changes due to inadequate digestion of tryptophan in patients with celiac disease (9). It has been reported that serotonergic dysfunction in the central nervous system may lead to mental alterations due to lack of tryptophan in the diet. In addition, it has been shown in many studies in which the symptoms of anxiety and depression are high in patients with celiac disease $(7,10)$.

Children with celiac disease have more physical, psychological and social problems than controls $(11,12)$. Patients without gluten-free diets were reported to have a lower quality of life, more physical problems and disease burden than patients with gluten-free diets, and that the family problems of patients without gluten-free diets were more severe (13). There is no consensus in the literature about nature the relationship between $C D$ and quality of life. Some studies show that celiac disease has a negative impact on the quality of life whereas some studies have reported that the disease does not change the quality of life (14-16).

Celiac disease affects negatively not only the children's mental health but also the parents' mental health (17). Changes in eating habits and living standards of celiac patients and their families impactnegatively the quality of life by emerging mental distress in parents cause of a strict and lifelong glutenfree diet $(16,18)$. It should not be forgotten that chronic illnesses like CD occur suddenly and unexpectedly and cause traumatic changes in the cycle of life (19). In addition, there are many psychiatric symptoms, especially depression and anxiety, in the mothers ofchildren with $C D$, and there were no studies of the traumatic effects in mothers due to this condition (20).

There was a limited amount of research in the literature that investigating the relationship between celiac disease and psychiatric disorders in the child and adolescent age group. Herein, it was aimed to screen the psychiatric disorders accompanying inchildren and adolescentswith $C D$, to determine depression and anxiety levels in these children, to identifying traumatic symptoms in mothers and to evaluate the quality of life of both patients and their mothers.

\section{METHOD and MATERIALS}

The study included 40 children and adolescents aged between 8-18 years who were diagnosed with celiac disease and their mothers. At evaluation time, children and adolescentpatients had been on follow-up for at least six months and all patients had been on the gluten-free diet. Patients with known genetic, neurological, endocrinological, metabolic, and mental illnesses were not included in the study. The control group consisted of volunteery 40 children and adolescents and their mothers. Children and adolescent in the control group were matched with the patient group in terms of age and sex, also childrenwith any known physical, psychiatric and chronic disease weren't included in the control group.
Socio-demographic data form was filled with a face-to-face interview.

Children and adolescents in the patient and control groups were asked to fill out the "Child Depression Inventory", "State-Trait Anxiety Inventory" and "State-Trait Anxiety Inventory for Children", "Pediatric Quality of Life Inventory-Child Self Report". Mothers of children and adolescents in the both groups were asked to fill out the "Post Traumatic Stress Disorder ChecklistCivilian Version (PCL-C)" and "Short Form-36 (SF-36)".

Ethical approval of the study was approved by Erciyes University Medical Faculty Ethics Committee (dated 18.04.2014, decision no: 2014/257). In accordance with the Declaration of Helsinki, all the families were informed about the study and a letter of approval informed in writing from the volunteers was obtained.

Children Depression Inventory (CDI)

The scale developed by Kovacs (1980) is used to measure the level of depression in children. It is a self-assessment scale that it is used in children and adolescents between 6-17 years of age. The validity and reliability of this inventory for Turkish society were studied by Oy (1991) (21).

State-Trait Anxiety Inventory (STAI)

The State-Trait Anxiety Inventory (STAI) developed by Spielberger is used to measure the level of anxiety (22). It consists of two scales those are the 20item state anxiety scale and the 20-item trait anxiety scale. Items in the scales are rated on 4-point likert-type scales. Turkish validity and reliability studies were conducted (23).

State-Trait Anxiety Inventory for Children (STAI-C)

The STAI-C is an instrument for measuring anxiety in children. This scale consists of twenty items aiming to evaluate feelings such as tension, nervousness, haste and uneasiness. Turkish validity and reliability study of this scale was conducted by Özusta (1995)(24).

Pediatric Quality of Life Scale (PedsQL)

The scale developed by Varni et al. (1999) is used for measuring the healthrelated quality of life of children and adolescents aged 2-18 (25). The Pediatric Quality of Life Inventory includes subscales to measure physical health, social, school and emotional functioning. Scale total score, physical health subscale score and psychosocial health subscale scores (consisting of calculation of item scores evaluating emotional, social and school functioning) are evaluated. The Turkish validity and reliability of the scale was made by Memik et al (2008) (26).

Short form 36 (SF-36)

SF-36 was developed by Rand Corporation in 1992 (27). Scores for each subscale are calculated separately. SF-36 subscale scores range from 0 to 100 , with higher scores indicating greater perceived health-related of quality of life. The validity of Turkish version of SF-36 was done by Koçyiğit et al. (28).

Post Traumatic Stress Disorder Checklist-Civilian Version (PCL-C)

The Turkish validity and reliability study of scale, first developed by Weathers and colleagues in 1993, was conducted by Kocabaşoğlu et al (29, 30). It is a self-assessed scale of a total of 17 items. It is used to assess symptoms of PTSD (cut-off score of 50).

\section{RESULTS}

Each group consisted of 17 males (42.5\%) and 23 females (57.5\%). In each groups, there are $22(55 \%)$ individuals in the 8-12 age group and $18(45 \%)$ individuals in the 13-18 age group. The mean age of the celiac and control group was $11.95 \pm 2.76$.

There was no significant difference between the celiac and control groups in terms of maternal age, father age, mother education level, mother and father occupations $(p=0.449, p=0.723, p=0.258, p=0.115, p=0.25$, respectively). No significant difference was found between the celiac and control groups in terms of "Children Depression Inventory" (Table 1).

Table 1. Comparing Children Depression Inventory Scores of Groups

\begin{tabular}{|c|c|c|c|c|}
\hline & & Celiac group & Control & $Z$ and $p$ value \\
\hline & & Median (25-75) & Median (25-75) & \\
\hline \multirow{2}{*}{ CDI score } & $8-12$ years old & $7,5(4,0-11,25)$ & $7,5(3,75-10,5)$ & $\begin{array}{l}Z=-0,330 \\
p=0,741\end{array}$ \\
\hline & $13-18$ years old & $8,5(4,75-15,5)$ & $9(8,0-19,0)$ & $\begin{array}{l}Z=-1,618 \\
p=0,111\end{array}$ \\
\hline
\end{tabular}


According to the children aged 8-12 years, the "State-Trait Anxiety Inventory for Children" scores of the Celiac group were found to be higher than the control group. No statistically significant difference was found between the groups of 13-18 age group in terms of "State-Trait Anxiety Inventory" scores (Table 2).

Table 2. Comparison of STAI and STAI-C Scores

\begin{tabular}{|c|c|c|c|c|}
\hline & $\mathrm{n}$ & Group & Median (25-75) & $Z$ and $p$ value \\
\hline \multirow{2}{*}{ State Anxiety Inventory for Children } & 22 & Celiac & $29 *(22,75-32,5)$ & $Z=-3,312$ \\
\hline & 22 & Control & $22,5(20,75-24,0)$ & $p=0,001$ \\
\hline \multirow{2}{*}{ Trait Anxiety Inventory for Children } & 22 & Celiac & $31 *(25,0-33,25)$ & $Z=-2,354$ \\
\hline & 22 & Control & $25(23,75-28,0)$ & $p=0,019$ \\
\hline \multirow{2}{*}{ State Anxiety Inventory } & 18 & Celiac & $39(27,75-45,5)$ & $Z=-0,460$ \\
\hline & 18 & Control & $38(30,0-46,75)$ & $p=0,650$ \\
\hline \multirow{2}{*}{ Trait Anxiety Inventory } & 18 & Celiac & $39,5(31,5-44,5)$ & $Z=-0,143$ \\
\hline & 18 & Control & $39(34,25-45,25)$ & $p=0,888$ \\
\hline
\end{tabular}

*Statistical significant

The groups were similar in terms of pediatric quality of life scalechild/adolescent and mothers' quality of life scale scores. (Table 3, Table 4, Table 5, Table 6).

Table 3. Comparison of PedsQL-Child Self of 8-12-year-olds

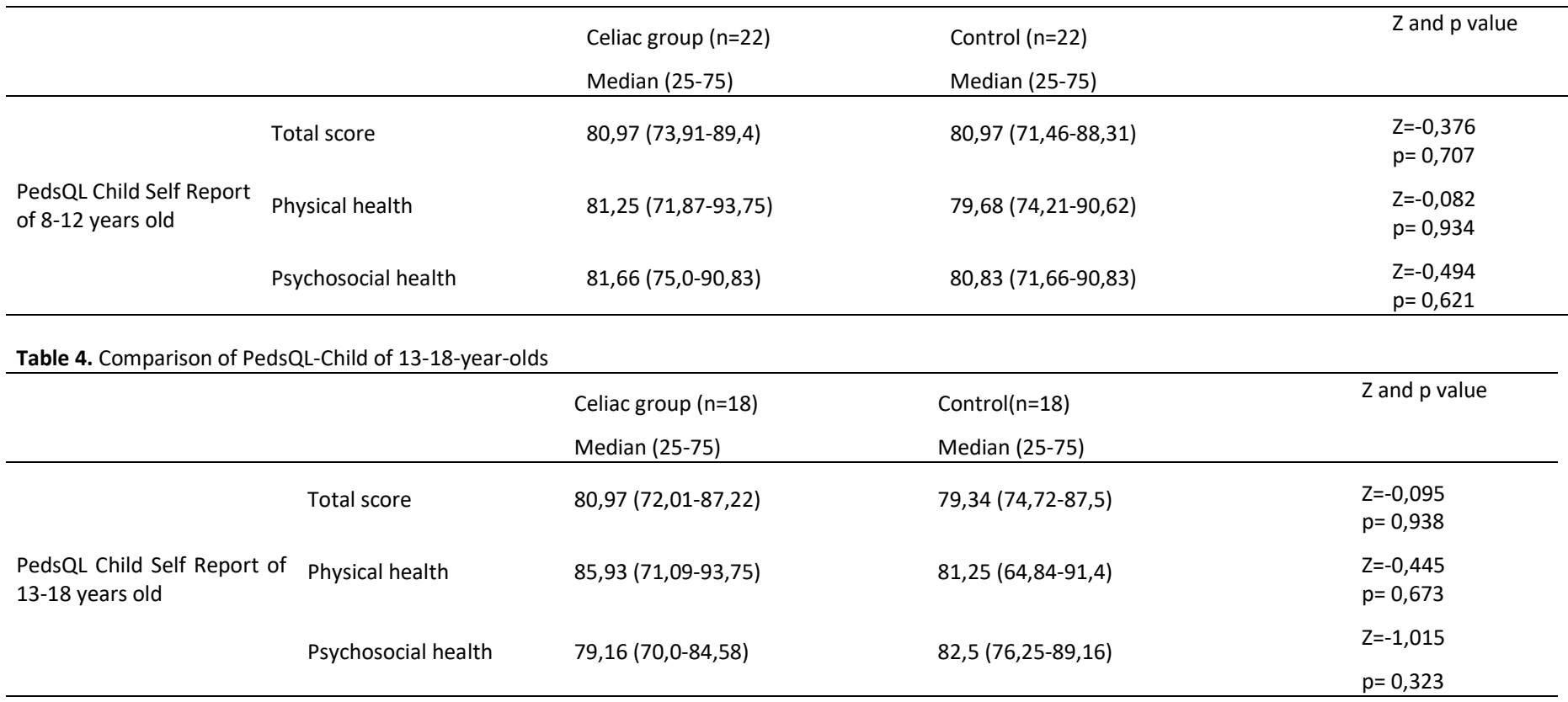

Table 5. Comparison of Quality of Life Scores of mothers in 8-12 years old groups

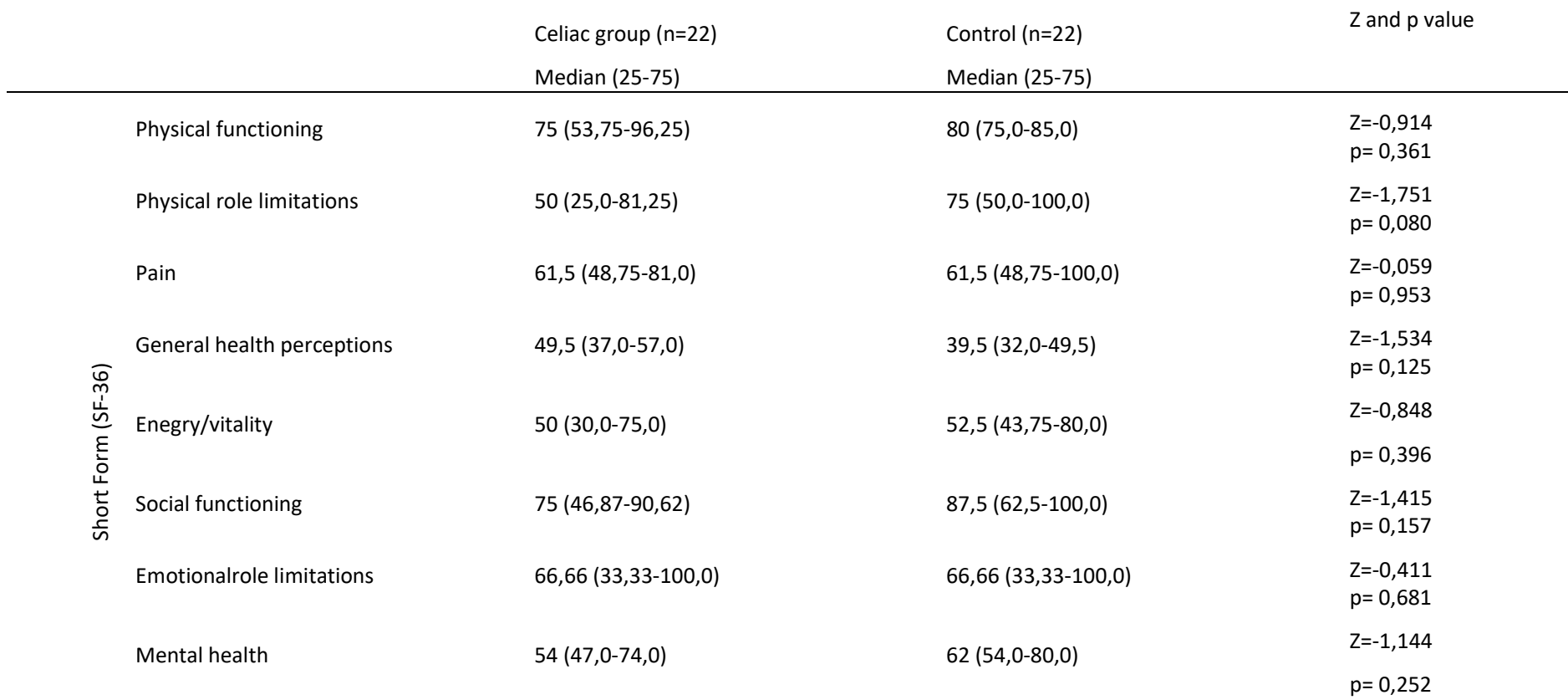


Table 6. Comparison of Quality of Life Scores of mothers in 13-18 years old groups

\begin{tabular}{|c|c|c|c|c|}
\hline & & Celiac group ( $n=18$ ) & Control $(n=18)$ & $Z$ and $p$ value \\
\hline & & Median (25-75) & Median (25-75) & \\
\hline & Physical functioning & $82,5(65,0-96,25)$ & $95(85,0-96,25)$ & $Z=-1,819$ \\
\hline & & & & $p=0,074$ \\
\hline & Physical role limitations & $75(50,0-100,0)$ & $75(0-100,0)$ & $Z=-0,641$ \\
\hline & & & & $p=0,542$ \\
\hline & Pain & $62(59,25-88,0)$ & $51(41,0-74,0)$ & $Z=-1,569$ \\
\hline & & & & $p=0,126$ \\
\hline & General health perceptions & $54,5(43,75-63,25)$ & $50(45,75-55,0)$ & $Z=-0,922$ \\
\hline & & & & $p=0,372$ \\
\hline ô & Enegry/vitality & $62,5(38,75-70,0)$ & $40(30,0-82,5)$ & $Z=-0,700$ \\
\hline$\frac{\vec{c}}{\varepsilon}$ & & & & $p=0,501$ \\
\hline 훈 & Social functioning & $87,5(59,37-100,0)$ & $81,25(56,25-100,0)$ & $Z=-0,033$ \\
\hline$\frac{\bar{c}}{n}$ & & & & $p=0,988$ \\
\hline & Emotional role limitations & $66,66(33,33-100,0)$ & $83,33(66,66-100,0)$ & $Z=-1,148$ \\
\hline & & & & $p=0,293$ \\
\hline & Mental health & $64(55,0-77,0)$ & $60(48,0-84,0)$ & $Z=-0,159$ \\
\hline & & & & $p=0,888$ \\
\hline
\end{tabular}

Compared to the control group, all subscale scores in the celiac group were significantly higher than the control in terms of PCL-C scores (Table 7).

Table 7. Comparison of mothers' PCL-C scores of groups

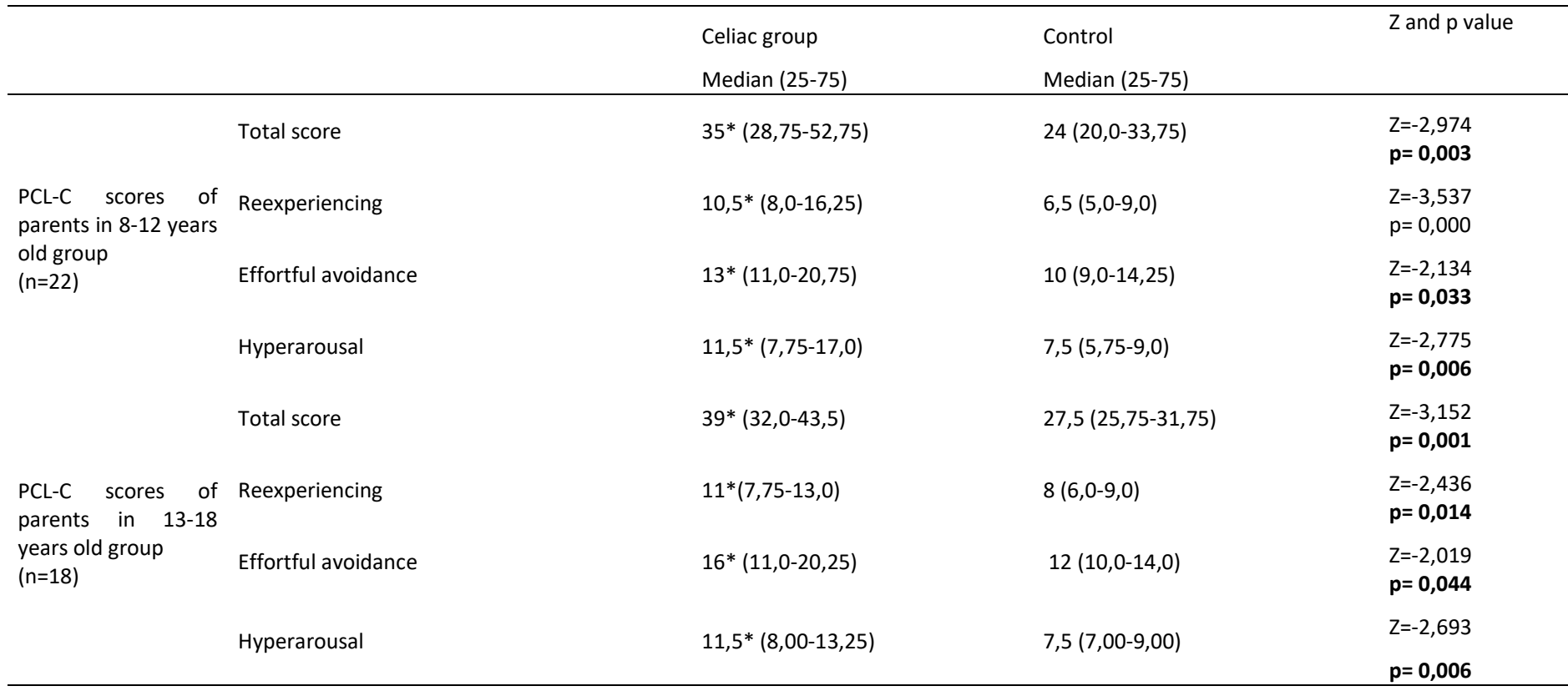

\section{DISCUSSION}

Celiac disease is one of the common causes of malabsorption all over the world and its symptoms negatively impact children's and adolescents' social activities and emotional state. As a result, CD cause psychiatric disorders and adversely affect the quality of life.In this research, to minimize any age-related changes and to eliminate any sex-related effects on the environmental and psychosocial variables, celiac group and control group matched in terms of age and gender.

Studies investigating the level of depression in patients with $C D$ have reported inconsistent results. In a study conducted by Arigo et al., 37\% of the patients were diagnosed with depression, and these symptoms were reported to increase psychosocial distress on the patients (31). Van Hees and colleagues reported that the prevalence of self-reported lifetime depression was $39 \%$ and point prevalence of depressive symptom was $11.9 \%$ (32). In addition, depressive symptoms were found to be independent of adherence types (strict, sufficient, insufficient) to gluten-free diet (32). Häuser et al. found no significant difference in depression levels between celiac group and control (33). In another study conducted with children and adolescents in Turkey, no significant difference was found between depression levels in the groups (34). The data obtained in present study support the literature that there was no significant difference in depression levels between the celiac disease and healthy population.

In most researches, anxiety levels in patients with celiac disease were often found to be high (35). In a year term follow-up study, Addolorato et al. found that after one-year gluten-free diet, state anxiety levels were higher than controls, and there was no difference between the levels of trait anxiety (35). Esenyel et al. reported that the anxiety levels of the patient and the control group were similar in the child and adolescent sample (34). In our study, the state-trait anxiety inventory scores for children were found to be high in accordance with the literature. On the contrary, no difference was found between the groups in adolescents. The lack of difference in adolescents may be due to the fact that the scale used is based on self-report and the adolescents desire to cope negative feelings and thoughts by themselves. 
A decline in quality of life is expected to experience in individuals with chronic illness due to the physical and psychological burden of illness. In earlier studies, it was found that the quality of life in celiac patients was generally lower than that of the control group $(36,37)$. In a multicenter study by Casellas et al., the quality of life was found to be lower in the newly diagnosed celiac group (36). Basso et al. reported that physical health subscale scores of quality of life in children and adolescents with celiac disease were lower than controls and that gender and duration of dieting did not appear to have a significant effect on quality of life (37). In contrast to these findings, Biagetti et al. didn't find any difference in quality of life between children and adolescents with celiac disease and healthy controls (38). According to the findings of our study, there was no statistically significant difference between the groups in terms of quality of life scale scores. Similar quality of life among groups can be explained by the fact that applying strict gluten-free diet, similar score of mothers' quality of life and protective effects of sufficient psychosocial support in celiac patients.

Children with physical health problems and their parents are at serious risk for psychiatric disorders such as depression and anxiety (17). The incidence of psychiatric disorders is also increasing due to psychological burden in the parents of children and adolescents with various chronic illnesses $(20,39)$. Ludvigsson et al. reported that depression and anxiety levels were higher in parents of children with CD than in controls (20). Similarly, Cabizuca et al. found that posttraumatic stress disorder in parents of children with chronic disease had a higher prevalence (39). In present study, total score of PCL-C and scores of reexperiencing, effortful avoidance, hyperarousal in mothers of celiac group were statistically higher than control group. This study findings suggest that mothers of children and adolescents with chronic illnesses may have an increased trauma findings as well as increased frequency of psychiatric illnesses.

At a time when the lifespan living with chronic illnesses increased, patients are suffering the difficulties of chronic diseases for a longer time. These difficulties cause physical, psychological, social and economic problems and affect negatively the quality of life of the individuals and their families $(6,7)$. De Lorenzo et al. reported that mothers' of children with CD social functioning (quality of life) scores were lower than in the control group (16). In our study, there was no difference between the groups in comparing the quality of life scores of mothers. These results were not as expected and may have been influenced by many situations. Children with CD may have nothad severe physical health problems because they have strictly adhered to their diet.In addition, there may be other reasons that lack of intensive interventional procedures applied to sick individuals and that parents' acceptance of their children's illnesses and coping with them.

\section{Conflict of interest}

No conflict of interest was declared by the authors.

\section{REFERENCES}

1.Troncone R, Jabri B. Coeliac disease and gluten sensitivity. J Intern Med 2011; 269: 582-90.

2.Singh P, Arora A, Strand TA, Leffler DA, Catassi C, Green PH, et al. Global prevalence of celiac disease: systematic review and meta-analysis. Clinical Gastroenterology and Hepatology 2018; 16:823-36.

3. Leonard MM, Sapone A, Catassi C, Fasano A. Celiac Disease and Nonceliac Gluten Sensitivity: A Review. Jama 2017; 318: 647-56

4. Husby S, Koletzko S, Korponay-Szabo I, Mearin M, Phillips A, Shamir R, et al. European Society for Pediatric Gastroenterology, Hepatology, and Nutrition guidelines for the diagnosis of coeliac disease. Journal of pediatric gastroenterology and nutrition 2012; 54: $136-60$.

5.Siniscalchi M, lovino P, Tortora R, Forestiero S, Somma A, Capuano L, et al. Fatigue in adult coeliac disease. Alimentary pharmacology \& therapeutics 2005; 22: 489-94.

6.Zingone F, Swift GL, Card TR, Sanders DS, Ludvigsson JF, Bai JC. Psychological morbidity of celiac disease: A review of the literature. United European Gastroenterology Journal 2015; 3: 136-45.

7.Ciacci C, lavarone A, Mazzacca G, De Rosa A. Depressive symptoms in adult coeliac disease. Scandinavian journal of gastroenterology 1998; 33: 247-50.

8.Ludvigsson JF, Reutfors J, Osby U, Ekbom A, Montgomery SM. Coeliac disease and risk of mood disorders-a general population-based cohort study. J Affect Disord 2007; 99: 117-26.

9.Karakoç MD. Çölyak hastalığı olan kadınların depresyon ve umutsuzluk düzeyleri. Endokrinolojide Diyalog 2015; 12: 41-4.
10.Mazzone L, Reale L, Spina M, Guarnera M, Lionetti E, Martorana S, et al. Compliant gluten-free children with celiac disease: an evaluation of psychological distress. BMC pediatrics 2011; 11: 46

11.Akdemir N, Birol L. İç Hastalıkları ve Hemşirelik Bakımı. Ankara: Sistem Ofset; 2005 193-200.

12.Rijken M, van Kerkhof M, Dekker J, Schellevis FG. Comorbidity of chronic diseases: effects of disease pairs on physical and mental functioning. Qual Life Res 2005; 14: 4555

13.Wagner G, Berger G, Sinnreich U, Grylli V, Schober E, Huber WD, et al. Quality of life in adolescents with treated coeliac disease: influence of compliance and age at diagnosis. J Pediatr Gastroenterol Nutr 2008; 47: 555-61.

14.Norstrom F, Lindholm L, Sandstrom O, Nordyke K, Ivarsson A. Delay to celiac disease diagnosis and its implications for health-related quality of life. BMC Gastroenterol 2011; 11: 118.

15.Nordyke K, Norstrom F, Lindholm L, Stenlund H, Rosen A, Ivarsson A, Health-related quality of life in adolescents with screening-detected celiac disease, before and one year after diagnosis and initiation of gluten-free diet, a prospective nested casereferent study. BMC Public Health 2013; 13: 142

16.De Lorenzo CM, Xikota JC, Wayhs MC, Nassar SM, de Souza Pires MM. Evaluation of the quality of life of children with celiac disease and their parents: a case-control study. Quality of Life Research 2012; 21: 77-85.

17.Feldman JM, Ortega AN, Koinis-Mitchell D, Kuo AA, Canino G. Child and family psychiatric and psychological factors associated with child physical health problems: results from the Boricua youth study. The Journal of Nervous and Mental Disease 2010; 198: 272.

18. Hornell A. Living well with celiac disease? J Pediatr Gastroenterol Nutr 2008; 47 544-6.

19.Alonzo A. The experience of chronic illness and post-traumatic stress disorder: the consequences of cumulative adversity. Soc Sci Med 2000; 50: 1475-84.

20.Ludvigsson JF, Roy A, Lebwohl B, Green PH, Emilsson L. Anxiety and depression in caregivers of individuals with celiac disease-A population-based study. Digestive and Liver Disease 2017; 49: 273-79.

21.Oy B, Çocuklar için depresyon ölçeği: Geçerlilik ve güvenirlik çalışması. Turk Psikiyatri Derg 1991; 2:132-35.

22.Spielberger CD, Gorsuch RL, Lushene RE. Manual for the State-Trait Anxiety Inventory. Palo Alto, CA: Consulting Psychologists Press. 1970.

23.Öner N, Le Compte A. Durumluk-Sürekli Kaygı Envanteri El Kitabı. İstanbul. Boğaziçi Üniversitesi Yayınları. 1985.

24.Özusta $H$. Çocuklar için durumlu-sürekli kaygı envanteri uyarlama, geçerlik ve güvenirlik çalışması. Türk Psikoloji Dergisi 1995; 10: 32-44.

25.Varni JW, Seid M, Rode CA. The PedsQL: measurement model for the pediatric quality of life inventory. Medical care 1999; 37: 126-39.

26.Memik NC, Ağaoğlu B, Coşkun A, Karakay I. Çocuklar Için yaşam kalitesi ölçeğinin 812 yaş çocuk formunun geçerlik ve güvenirliği. Çocuk ve Ergen Ruh Sağlığı Dergisi 2008; 15: 87-98.

27.Ware Jr JE, Sherbourne CD. The MOS 36-item short-form health survey (SF-36): I. Conceptual framework and item selection. Medical care 1992: 473-83.

28. Koçyiğit H, Aydemir Ö, Fişek G, Ölmez N, Memiş AK. Form-36 (KF-36)'nın Türkçe versiyonunun güvenilirliği ve geçerliliği. Ilaç ve tedavi dergisi 1999; 12: 102-6. 29. Weathers FW, Litz BT, Herman DS, Huska JA, Keane TM. The PTSD Checklist (PCL): Reliability, validity, and diagnostic utility. 9th annual convention of the international society for traumatic stress studies, San Antonio, TX. 1993.

30.Kocabaşoğlu N, Çorapçıoğlu Özdemir A, Yargıç i, Geyran P. PTSD Checklist-Civilian Version Ölçeğinin geçerlilik ve güvenilirliği. Yeni Symposium 2005; 43: 126-34.

31.Arigo D, Anskis AM, Smyth JM. Psychiatric comorbidities in women with celiac disease. Chronic illness 2012; 8: 45-55.

32.Van Hees NJ, Van der Does W, Giltay EJ. Coeliac disease, diet adherence and depressive symptoms. Journal of psychosomatic research 2013; 74: 155-60.

33. Häuser W, Janke K-H, Klump B, Gregor M, Hinz A. Anxiety and depression in adult patients with celiac disease on a gluten-free diet. World journal of gastroenterology 2010; 16: 2780.

34.Esenyel S, Unal F, Vural P. Depression and anxiety in child and adolescents with follow-up celiac disease and in their families. The Turkish journal of gastroenterology: the official journal of Turkish Society of Gastroenterology 2014; 25: 381-5.

35.Addolorato G, Mirijello A, D'Angelo C, Leggio L, Ferrulli A, Vonghia L, et al. Socia phobia in coeliac disease. Scandinavian journal of gastroenterology 2008; 43: 410-5. 36.Casellas F, Rodrigo L, Lucendo AJ, Molina-Infante J, Vivas S, Rosinach M, et al. Benefit on health-related quality of life of adherence to gluten-free diet in adult patients with celiac disease. Revista Española de Enfermedades Digestivas 2015; 107 : 196-201.

37.Basso M, Crisogianni M, Di Ciommo V, Bracci F, Ferretti F, Baldini D, et al. Healthrelated quality of life in children and adolescents affected by coeliac disease. Digestive and Liver Disease 2007; 39: A55.

38.Biagetti C, Gesuita R, Gatti S, Catassi C. Quality of life in children with celiac disease: A paediatric cross-sectional study. Digestive and Liver Disease 2015; 47: 927-32.

39.Cabizuca M, Marques-Portella C, Mendlowicz MV, Coutinho ES, Figueira I. Posttraumatic stress disorder in parents of children with chronic illnesses: a metaanalysis. Health Psychology 2009; 28: 379. 